\title{
Blood DNA Analysis for Ehrlichia (Anaplasma) phagocytophila and Babesia spp. of Dogs from Northern Poland
}

\author{
B. SKOTARCZAK, M. ADAMSKA, M. SUPRON
}

Department of Genetics, Faculty of Natural Science, University of Szczecin

\author{
Received October 21, 2003
}

Accepted July 29, 2004

\section{Abstract}

Skotarczak B., M. Adamska, M. Supron: Blood DNA Analysis for Ehrlichia (Anaplasma) phagocytophila and Babesia spp. of Dogs from Northern Poland. Acta Vet. Brno 2004, 73:347-351.

The most common pathogen transmitted by the tick Ixodes ricinus is the spirochete Borrelia burgdorferi, rarely Ehrlichia bacteria and protozoans from the Babesia genus. The aim of this paper was determine if infested to ticks dogs are a reservoir for E. phagocytophila and Babesia spp. and examine the possibility of coinfection. Canine blood was sampled, part of the material originated from dogs exhibiting symptoms of borreliosis. In an earlier study, the samples were screened for DNA from B. burgdorferi sensu lato. In order to screen for E. phagocytophila and Babesia spp. DNA, a PCR-based method was used with the following primers: EHR521/EHR747 for Ehrlichia and FOR1/REV1 for Babesia. In 192 samples only two contained E. phagocytophila DNA. One of these samples originated from a healthy canine, the other from an individual with symptoms of borreliosis. The examined samples were not positive for Babesia spp DNA. Coinfection was not discovered. The low level of E. phagocytophila infection may indicate that the domestic dog is not a reservoir for Ehrlichia and Babesia in Szczecin and northwestern Poland. Moreover, this area does not have populations of the brown dog tick (Rhipicephalus sanguineus) or Dermacentor reticulatus - both of which are vectors of E. canis and B. canis and commonly induce ehrlichiosis and babesiosis in canines.

Ehrlichia (Anaplasma) phagocytophila, Babesia spp. dogs, PCR

Infections caused by the spirochete Borrelia burgdorferi sensu lato may be accompanied by other microorganisms, such as Ehrlichia and Babesia. Recently, reports of coinfection with multiple tick-borne organisms in humans and dogs have been published (Hofmeister et al. 1998; Krause 1996, 2002; Kordick et al. 1999; Skotarczak et al. in press).

Ehrlichia canis is a widely distributed species and commonly occurs in canines (McDade 1990; Rikihisa 1991). Other Ehrlichia species, infrequently found in dogs, include $E$. platys (Chang and Pan 1996; Sainz et al. 1999), E. ewingii (Goodman et al. 2003) and the HGE agent, currently identified with E. phagocytophila (Egenvall et al. 2000; Magnarelli et al. 1997, 2001). Aetiological factors in canine babesiosis are comprised of two species: B. gibsoni and B. canis with 3 subspecies, additionally a third uncommon agent called B. microti-like has been documented (Camacho et al. 2002; Zahler et al. 2000). The prevalence of the pathogens is largely dependent on the distribution of their vectors. Tick vectors for E. canis (Rhipicephalus sanguineus) and B. canis (R. sanguineus and Dermacentor reticulatus) do not inhabit northwestern Poland. However, a common tick species in Poland and northern Europe is Ixodes ricinus.

Research involving PCR amplification of pathogen DNA in I. ricinus collected from forested localities in Szczecin and northwestern Poland has revealed the presence of B. burgdorferi s.l. (from 0.3 to $15.7 \%$ ) in all life stages of the tick over a period of several years (Skotarczak and Wodecka 1998, 2000). Other studies using ticks from the same localities have informed of finding DNA from B. microti and B. divergens and also the

ddress for correspondence:

Prof. Bogumila Skotarczak

Department of Genetics

Faculty of Natural Science

Phone/fax: +48914442780

Al. Piastow 40b, 71-065 Szczecin, POLAND

E-mail·Bogumila_Skotarczak@univ.szczecin.pl

http://www.vfu.cz/acta-vet/actavet.htm 
human granulocytic ehrlichiosis agent (E. phagocytophila), first as single tick infections (Skotarczak and Cichocka 2001a, 2001b; Skotarczak and Rymaszewska 2001; Skotarczak et al. 2003a) and later as double and triple coinfections (Skotarczak et al. 2002, 2003b). A similar study has shown the presence of the human granulocytic ehrlichiosis agent and also the aetiological factor inducing Lyme borreliosis in I. ricinus from North of Poland (Stańczak et al. 2002).

The results of studies of sera and the detection of spirochete DNA in canine blood show that dogs naturally exposed to ticks in Szczecin and neighboring areas, endemic for I. ricinus and borrelias, are a reservoir for B. burgdorferi s.l. (Skotarczak and Wodecka 2003; Skotarczak et al. in press). In the present study, the same population of dogs was been screened for the presence of E. phagocytophila and Babesia spp. DNA in order to investigate the possibility of coinfection and to evaluate the status of dogs from northwestern Poland as a potential reservoir for these pathogens.

\section{Materials and Methods}

Blood samples were taken from 192 dogs naturally exposed to I. ricinus ticks. Canine borreliosis was suspected by veterinarians in 92 of them. Remaining 100 individuals of different breeds were from Szczecin's dog shelter and were healthy. The age (from 0.5 to 14 years), sex and breed of the individuals was noted, and also infestation by ticks in the past and present. Blood used in the serological study and PCR's was sampled immediately after periods of pronounced activity of ticks, i.e. from June to the middle of July and from September to the middle of October.

DNA was isolated from blood samples using the QIAamp ${ }^{\circledR}$ DNA Mini Kit (Qiagen, Germany) according to the attached protocol. In order to amplify a fragment of the 16S rRNA gene of E. phagocytophila, the primers EHR521 and EHR747 were used, which give a product of $247 \mathrm{bp}$ (Guy et al. 1998). As a positive control we used HGE agent DNA from a culture of HL 60 cells, MRL Diagnostics (Stańczak et al. 2002). PCR amplifications involved an initial denaturation step at $94{ }^{\circ} \mathrm{C}$ for $2 \mathrm{~min} ; 35$ cycles of denaturation at $94{ }^{\circ} \mathrm{C}-30$ seconds, primer annealment $64{ }^{\circ} \mathrm{C}-45 \mathrm{~s}$, extension at $72{ }^{\circ} \mathrm{C}-30 \mathrm{~s}$, final extension at $72{ }^{\circ} \mathrm{C}-5 \mathrm{~min}$. Reagents used in the reactions were from Fermentas (Lithuania).

In order to detect protozoans from the Babesia genus by the PCR method we used the primers FOR1 (5'TGTCTT-AAA-GAT-TAA-GCC-ATG-CAT-GT3') and REV1 (3'CTT-CTT-TTA-AGT-GAT-AAG-GTT-CACAA5') which amplify a fragment of the 18S rRNA gene and are widely specific for the genus with a product of $1700 \mathrm{bp}$. PCR amplifications involved an initial denaturation step at $94^{\circ} \mathrm{C}$ for $3 \mathrm{~min} ; 35$ cycles of denaturation at $94{ }^{\circ} \mathrm{C}-45 \mathrm{~s}$, primer annealment $65^{\circ} \mathrm{C}-45 \mathrm{~s}$ (FOR1 and REV1), elongation at $72^{\circ} \mathrm{C}-1 \mathrm{~min}$ and $30 \mathrm{~s}$, final elongation at $72{ }^{\circ} \mathrm{C}-7 \mathrm{~min}$. The product of the first reaction was diluted $20 \times$ and reamplified.

PCR's also incorporated negative and positive controls. Reactions were performed in a T-gradient (Biometria, Germany) thermocycler, reactions for each sample were repeated. The products were separated in $2 \%$ (HGE agent) or $1.5 \%$ agarose (Babesia spp.) (ICN, USA) with ethidium bromide (Sigma-Aldrich, Germany) at $80 \mathrm{~V}$ for $1.5 \mathrm{~h}$. In order to evaluate the size of the amplified fragments, a molecular mass marker (Polgen) with bands between 501 and $110 \mathrm{bp}$ was used for the HGE agent or SmartLadder, Bioline, Germany for the Babesia spp. The PCR products were visualized in UV light and computer-archived with the BioCapt program (Vilber Lourmat, France) which analyses the image from the transilluminator. A positive result in the PCR's was inferred by the presence of bands of the appropriate molecular mass.

\section{Results and Discussion}

In 192 blood samples only two $(1.0 \%)$ were found to be positive by PCR for E. phagocytophila DNA. One of the infected samples came from a healthy dog, the other from a dog with symptoms of borreliosis. The two infected individuals did not have B. burgdorferi $\mathrm{s}$. 1. DNA in their blood. The presence of Babesia protozoans DNA was not detected in none of 192 blood samples.

Both humans and dogs infected with multiple tick-borne agents can experience a wide range of clinical manifestations (Farwell et al. 1982; Boustani and Gelfand 1996; Harrus et al. 1997). However, the consequences of co-infection have not been well established in either, compared with infection by one agent only (Kordick et al. 1999).

Ehrlichiosis is a disease affecting many bodily systems and can have a mild or severe course, partly determined by the species of Ehrlichia and type of infected blood cells. The state of the immunological system of the host is of utmost importance. Serious infections 
result in long-term complications, mainly haemorrhage and secondary infections, often leading to death.

In Europe the most widely distributed species of Ehrlichia is the HGE agent infecting mostly humans. It belongs to one genogroup with E. equi and E. phagocytophila and induces granulocytic ehrlichiosis (Rikihisa 1997). In 2001, Dumler and colleagues proposed to combine the mentioned species into one species, Anaplasma phagocytophila, on the basis of similarities in the groESL gene, the 16S rRNA gene of the small ribosomal subunit and genes coding for surface proteins. The primers used in our study were complementary to the 16S rRNA gene for all three species.

Ehrlichias from the E. phagocytophila genogroup were found in canine blood by serological methods (Egenvall et al. 2000; Magnarelli et al. 1997, 2001) and PCR (Breitschwerdt et al. 1998; Greig et al. 1996; Johansson et al. 1995; Kordick et al. 1999)

Clinical diagnosis of canine granulocytic ehrlichiosis (CGE) is difficult. Two distinct clinical syndromes, including chronic, moderate to severe anemia and polyarthritis are associated with CGE (Goldman et al. 1998). Clinical signs are nonspecific and include fever, lethargy, anorexia, vomiting, and diarrhoea.

The dog from the group of healthy individuals, naturally exposed to I. ricinus, whose blood contained E. phagocytophila (A. phagocytophila) DNA did not exhibit symptoms of the active form of this infection. Similarly, the PCR+ individual from the group with diagnosed borreliosis did not exhibit symptoms of ehrlichiosis, only arthritis and a high level of $B$. burgdorferi s. l. antigens characteristic of the former disease. The ehrlichiosis infection was probably in a phase before ehrlichiosis proliferation.

Protozoans from the genus Babesia have been found in canine blood by using a PCRbased method with species-specific primers amplifying different fragments of the 16S rRNA and 18S rDNA genes (Zahler et al. 1998; Carret et al. 1999; Ca macho et al. 2002). We constructed a pair of genus-specific primers complementary to the 18S rRNA gene. These primers can amplify DNA from B. canis canis, B. canis vogeli, B. gibsoni, B. divergens, B. microti (UO9833, AB032434, AF188001 "spanish dog", AF231349 "strain Berlin", AB071177-"strain Munch", AB085191-"strain Hannover"), B. odocoilei, B. rodhaini and Theileria spp. The negative results for the presence of Babesia DNA in canine blood is probably the result of the lack of appropriate vectors for Babesia species in the studied area.

\section{DNA Ehrlichia (Anaplasma) phagocytophila a DNA Babesia spp. $v$ krvi psů v severním Polsku}

Nejčastěǰ̌i patogeny přenášené klíštetem Ixodes ricinus je spirocheta Borrelia burgdorferi, vzácně bakterie Ehrlichia a protozoa rodu Babesia. Cílem této studie bylo zjistit, zda jsou psi nakažení klíštětem - rezervoárem E. phagocytophila a Babesia spp. a prověřit možnost infekce oběma patogeny zároveň. Byla testována krev psủ, přičemž část vzorků pocházela od psů se symptomy boreliózy. Při studii byla ve vzorcích nejprve zjištována př́itomnost DNA B. burgdorferi. Za účelem průkazu DNA E. phagocytophila a Babesia spp. byla použita metoda PCR s využitím následujících primerů: EHR521/EHR747 pro ehrlichie a FOR1/REV1 pro babesie. Ze 192 vzorků jen dva obsahovaly DNA E. phagocytophila. Jeden z těchto vzorkủ byl odebrán zdravému psovi, ostatní od jedinců se symptomy boreliózy. Ve zkoumaných vzorcích nebyla zjištěna prítomnost DNA Babesia spp. Infekce oběma patogeny zároveň nebyla zaznamenána. Nízká prevalence výskytu E. phagocytophila může indikovat, že pes domácí není rezervoárem Ehrlichia a Babesia ve Štětíně a severozápadním Polsku. Navíc se v této oblasti nevyskytují klištata Rhipicephalus sanguineus či 
Dermacentor reticulatus, která jsou vektory E. canis a $B$. canis a často způsobují ehrlichiózu a babesiózu psů.

\section{References}

BOUSTANI, MR, GELFAND, JA 1996: Babesiosis. Clin Infect Dis 22: 611-615

BREITSCHWERDT, EB, HEGARTY, BC, HANCOCK, SI 1998: Sequential evaluation of dogs naturally infected with Ehrlichia canis, Ehrlichia chaffeensis, Ehrlichia equi, Ehrlichia ewingii or Bartonella winsoni. J Clin Microbiol 36: 2645-2651

CAMACHO, AT, PALLAS, E, GESTAL, JJ, GUITIÁN, FJ, OLMEDA, AS 2002: Natural infection by a Babesia microti-like piroplasms in a splenectomised dog. Vet Rec 150: $381-382$

CARRET, C, WALAS, F, CARCY, B, GRANDE, N, PRÉCIGOUT, E, MOUBRI, K, SCHETTERS, TP, GORENFLOT, A 1999: Babesia canis canis, Babesia canis vogeli, Babesia canis rossi: Differentation of the three subspecies by a restriction fragment length polymorfism analysis on amplified small subunit ribosomal RNA genes. J Eucaryot Microbiol 46: 298-303

CHANG, WL, PAN, MJ 1996: Specific amplification of Ehrlichia platys DNA from blood specimens by two-step PCR J Clin Microbiol 34: 3142-3146

EGENVALL, A, BONNET, BN, GUNNARSSON, A, HEDHAMMAR, A, SHOUKRI, M, BORNSTEIN, S, ARTURSSON, K 2000: Sero-prevalence of granulocytic Ehrlichia spp. and Borrelia burgdorferi sensu lato in Swedish dogs 1991-94. Scand J Infect Dis 32: 19-25

FARWELL, GE, LEGRAND, EK, COBB, CC 1982: Clinical observations on Babesia gibsoni and Babesia canis infection in dogs. J Am Vet Med Assoc 180: 507-11

GOLDMAN, EE, BREITSCHWERDT, EB, GRINDEM, CB, HEGARTY, BC, WALLS, JJ, DUMLER, JS 1998 : Granulocytic ehrlichiosis in dogs from North Carolina and Virginia. J Vet Int Med 12(2): 61-70

GOODMAN, RA, HAWKINS, EC, OLBY, NJ, GRINDEM, CB, HEGARTY, B, BREITSCHWERDT, EB 2003: Molecular identification of Ehrlichia ewingii infection in dogs: 15 cases (1997-2001). J Am Vet Med Assoc 222: $1102-7$

GREIG, B, ASANOVICH, KM, ARMSTRONG, PJ, DUMLER, JS 1996: Geographic, clinical, serologic and molecular evidence of granulocytic ehrlichiosis, a likely zoonotic disease, in Minnesota and Wisconsin dogs. J Clin Microbiol 34: 44-48

GUY, E, TASKER, S, JOYNSON, DHM 1998: Detection of the agent of human granulocytic ehrlichiosis (HE) in UK ticks using polymerase chain reaction. Epidemiol Infect 121: 681-683

HARRUS, S, KASS, PH, KLEMENT, E, WANER, T 1997: Canine monocytic ehrlichiosis: a retrospective study of 100 cases, and an epidemiological investigation of prognostic indicator for the disease.Vet Rec 141: 360-3

HOFMEISTER, EK, KOLBERT, CP, ABDULKARIN, AS, MAGERA, JMH, HOPKINS, MK, UHL, JR, AMBYAYE, A, TELFORD, SR, COCKERILL, FR, PERSING, DH 1998: Cosegregation of a novel Bartonella species with Borrelia burgdorferi and Babesia microti in Peromyscus luecopus. J Infect Dis 177: 409-16

JOHANSSON, KE, PETTERSSON, B, UHLEN, M, GUNNARSSON, A, MALMQVIST, M, OLSSON, E 1995: Identification of the causative agent of granulocytic ehrlichiosis in Swedish dogs and horses by direct solid phase sequencing of PCR products from the 16S rRNA gene. Res Vet Sci 58: 109-112

KORDICK, SK, BREITSCHWERDT, EB, HEGARTY, BC, SOUTHWICK, KL, COLITZ, CM, HANCOCK, SI, BRADLEY, JM, RUMBOUGH, R, MCPHERSON, JT, MacCORMACK, JN 1999: Coinfection with multiple tick-borne pathogens in a walker hound kennel in North Carolina. J Clin Microbiol 37: 2631-2638

KRAUSE, PJ, RAYMOND, R, TELFORD III, S, PERSING, D, SPIELMAN, A 1996: Efficiacy of immunoglobulin M serodiagnostic test for rapid diagnosis of acute babesiosis. J Clin Microbiol 34: 2014-2016 KRAUSE, PJ, MCKAY, K, THOMPSON, CA, SIKAND, VK, LEPORE, T, CLOSTER, L, CHRISIANSON, D, TELFORD, SR, PERSING, D, RADOLF, JD, SPIELMAN, A 2002: Disease-specific diagnosis of coinfecting tickborne zoonoses: babesiosis, human granulocytic ehrlichiosis, and Lyme disease. Clin Infect Dis 34: 11841191

MAGNARELLI, LA, IJDO, JW, ANDERSON, JF, MADIGAN, JE, DUMLER, JS, FIKRIG, E 1997: Antibodies to Ehrlichia equi in dogs from the northeastern United States. J Am Vet Med Assoc 211: 1134-1137

MAGNARELLI, LA, IJDO, JW, VAN ANDEL, AE, WU, C, FIKRIG, E. 2001. Evaluation of a polyvalent enzyme-linked immunoabsorbent assay incorporating a recombinant $\mathrm{p} 44$ antigen for diagnosis of granulocytic ehrlichiosis in dogs and horses. Am J Vet Res 62:29-32

McDADE, J 1990: Ehrlichiosis - a disease of animals and humans. J Infect Dis 161: 609-617

RIKIHISA, Y 1991: The tribe Ehrlichia and ehrlichial diseases. Clin Microbiol Rev 4: 286-308

RIKIHISA, Y 1997: Emerging and re-emerging diseases transmitted by arthropod vectors and rodents. Proceedings of the 2nd International Symposium of Lyme Disease in Japan, Shizuoka, Oct. 27-28, 1997

SAINZ, A, AMUSATEGUI, I, TESOURO, MA 1999: Ehrlichia platys infection and disease in dogs in Spain. J Vet Diagn Invest 11: 382-384 
SKOTARCZAK, B, WODECKA, B 1998: Occurrence of spirochetes Borrelia burgdorferi sensu lato in ticks Ixodes ricinus in the forest of Szczecin province. Wiad Parazytol 2: 227-232

SKOTARCZAK, B, WODECKA, B 2000: Use of polymerase chain reaction (PCR) for detection of Borrelia burgdorferi sensu lato in screening studies. Folia Med Cracov 3-4: 35-42

SKOTARCZAK, B, CICHOCKA, A 2001a: Isolation and amplification by polymerase chain reaction DNA of Babesia microti and Babesia divergens in ticks in Poland. Ann Agric Environ Med 8: 187-9

SKOTARCZAK, B, CICHOCKA, A 2001b: The occurrence DNA of Babesia microti in ticks Ixodes ricinus in the forest areas of Szczecin. Folia Biol (Krakow) 49: 247-50

SKOTARCZAK, B, RYMASZEWSKA, A 2001: Prevalence of the etiological agent of human ehrlichiosis (HE) in ticks from west-north Poland. Wiad Parazytol 47: 95-101

SKOTARCZAK, B, WODECKA, B 2003: Molecular evidence of the presence of Borrelia burgdorferi sensu lato in blood samples taken from dogs in Poland. Ann Agric Environ Med 10: 113-5

SKOTARCZAK, B, WODECKA, B, CICHOCKA, A 2002: Coexistence DNA of Borrelia burgdorferi sensu lato and Babesia microti in Ixodes ricinus ticks from north-western Poland. Ann Agric Environ Med 9: 25-29

SKOTARCZAK, A, RYMASZEWSKA, A, ADAMSKA, M. 2003a: Polymerase chain reaction in detection of human granulocytic ehrlichiosis (HGE) agent DNA in Ixodes ricinus ticks. Folia Med Cracov 1-2: 205-212

SKOTARCZAK, B, RYMASZEWSKA, A, WODECKA, B, SAWCZUK, M. 2003b: Molecular evidenca of coinfection of Borrelia burgdorferi sensu lato, human granulocytic ehrlichiosis agent, and Babesia microti in ticks from northwestern Poland. J Parasitol 89: 194-196

SKOTARCZAK, B, RYMASZEWSKA, A, WODECKA, B, SAWCZUK, M. Domestic dog as a reservoir of Borrelia burgdorferi sensu lato spirochetes from endemic areas of Lyme disease in Poland. J Spiro Tick-borne Dis, in press.

STAŃCZAK, J, RACEWICZ, M, KRUMINIS-LOZOWSKA, W, KUBICA-BIERNAT, B 2002: Coinfection of Ixodes ricinus (Acari: Ixodidae) in northern Poland with the agents of Lyme borreliosis (LB) and human granulocytic ehrlichiosis (HGE). Int J Med Microbiol 33: 198-201

WODECKA, B, SKOTARCZAK, B 2000: Genetic diversity of Borrelia burgdorferi sensu lato in Ixodes ricinus ticks collected in north-west Poland. Wiad Parazytol 4: 475-485

ZAHLER, M, SCHEIN, E, RINDER, H, GOTHE, R 1998: Characteristic genotypes discriminate between Babesia canis isolates of differing vector specify and pathogenicity to dogs. Parasitol Res 84: 544-8

ZAHLER, M, RINDER, H, SCHEIN, E, GOTHE, R 2000: Detection of a new pathogenic Babesia microti-like species in dogs. Vet Parasitol 89: 241-248 